\title{
En e-læringsstrategi er ikke nok - men den er ikke så dårlig endda!
}

\author{
Ambrosia Hansen \\ Master i læreprocesser \\ E-læringskoordinator \\ Syddansk Universitet \\ aha@adm.sdu.dk \\ http://www.sdu.dk
}

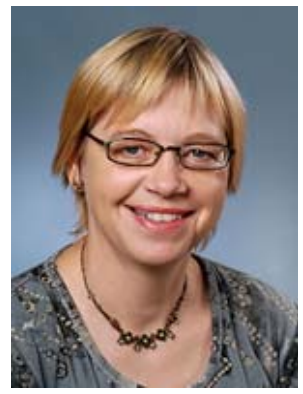

Ambrosia Hansen er e-læringskoordinator på Syddansk Universitet og har været ansat i denne stilling i to år. I den tid har hun vcret med til at udforme og implementere universitetets $e$ leringsstrategi. Hun har desuden været ansvarlig for processen vedr. valg af universitetets eleringsplatform, Blackboard.

\section{Indledning}

Syddansk Universitet har medio 2004 taget en ny version af e-læringssoftwaren Blackboard i brug. Valget af netop denne software synes i dag at måtte have været ligetil: Systemet indeholder en lang række muligheder, som understøtter et bredt udvalg af universitets funktioner, den tekniske implementering er (som man husker det i dag) overstået uden voldsomme problemer, arbejdet med at integrere systemet med øvrige systemer - en mangfoldighed af mailsystemer, studieadministrationssystemer mm. - har bevæget sig støt (men roligt) i den rigtige retning, og store dele af universitetets ansatte kan se potentialer i systemet og er så småt begyndt at anvende det. Men alt har ikke været så ligetil, som det i gode tider kan se ud, og vejen til en fuldstændig implementering i og integrering med universitetet er fortsat lang. Med vedtagelsen af en e-læringstrategi i efteråret 2003, har universitetet fået et godt afsæt for en række initiativer, der er med til at understøtte og udvikle e-læring på alle niveauer i organisationen. I artiklen beskrives på baggrund af en gennemgående case det arbejde, der ligger bag implementeringen af e-læring på SDU.

\section{E-læringsstrategien}

Når man i en organisation har besluttet sig for at indføre e-læring, sker indførelse langt fra så nemt, at man køber et system og begynder at anvende det. Forud for køb - dvs. valg - af system ligger mange overvejelser, svære beslutninger, som skal tages, og ikke mindst en lang række initiativer, som skal iværksættes og føres ud i livet. Og desuden gør det sig ifølge erfaring fra elæringsimplementering på SDU gældende, at hvert af disse delprojekter er yderst komplekst. Således er der i høj grad brug for koordinering og struktur. E-læring handler ikke længere om at 'sætte strøm' til lærebøgerne og undervisningslokalet. Nye pædagogiske metoder og mange nye softwareløsninger giver mulighed for at finde frem til løsninger, som modsvarer forskellige former for behov. Syddansk Universitet har i e-læringsstrategien formuleret det således, at "Universitetets overordnede målsætning er at skabe et virtuelt universitet, hvor alle medarbejdere og studerende har adgang til IKT-mæssige funktioner og informationer uanset geografisk placering. 
Inden for kontraktperioden sigter universitetet mod en fortsat udbygning af de eksisterende IKTfaciliteter, men i særdeleshed mod at udbygge de kvalitative dimensioner af IKT-anvendelse inden for forskning, undervisning og administration. Målet er at gøre IKT til en naturlig og integreret del af alle universitetets funktioner,"

I relation hertil indgik der i forbindelse med beslutningen om valg af e-læringsplatform en række kriterier, som f.eks.:

- At der var mulighed for en mangfoldighed af læringsaktiviteter og dermed forskellige pædagogiske tilgange;

- At systemet var nemt at gå til og komme i gang med også for den mindre it-kyndige - og at der var udfordringer for de undervisere og studerende, der havde lyst til at anvende systemet mere avanceret;

- At der var mulighed for integration med studieadministrative systemer, således at flest mulige processer i forbindelse med oprettelse af hold og tilknytning af undervisere og studerende kunne automatiseres og dermed gøre opgaven overkommelig for det administrative personale.

Med valget fulgte også overvejelser og konkrete initiativer i forbindelse med, hvad der skulle til for at medarbejdere og studerende nemt og smertefrit kom i gang med at anvende Blackboard. En koordinering af indsatsen på tværs af organisationen er af stor betydning, således at erfaringer og gode initiativer kan spredes og udnyttes i andre dele af 'huset'. Forskellige former for støtte og support - både som fremmøde og elektronisk, har SDU gode erfaringer med, og disse initiativer vil blive omtalt senere i denne artikel. Det har i den forbindelse været helt afgørende, at hvert fakultet har sin egen e-læringskoordinator, der er bekendt med, hvilke behov medarbejderne har og kan sætte lokale initiativer i gang samt samarbejde med de øvrige koordinatorer om fælles tiltag. Det lokale arbejde med e-læring har desuden stor betydning i forbindelse med etablering af kendte procedurer og processer, således at ikke alting skal forhandles på ny hver gang. Sidst men ikke mindst får det lokale arbejde betydning for den strategiske forankring, som er nødvendig for at processerne lykkedes.

Et af målene med dette arbejde er nemlig, at ønsket om at anvende e-læring ikke skal opleves som et krav og en forventning, andre har formuleret. Både medarbejdere og studerende skal erfare, at de med e-læring får bedre muligheder for at udvikle deres kompetencer, og at de får flere strenge at spille på. Det kunne illustreres på denne måde:

Underviserne på centret er blevet opfordret til at deltage i en såkaldt Blackboard-dag på instituttet. Som der står i mailen udsendt fra deres dekan, er der implementeret en ny version af Blackboard og taget en beslutning om, at den nu skal bruges. På universitetet er man nået til enighed om, at de studerende inden for et år skal kunne finde informationer om deres forskellige fag og det samlede studium i Blackboard. Derfor kan instituttets undervisere ligeså godt komme igang med at afprøve og anvende systemet.

Nogle synes, det er en spæendende udfordring, som de ser frem til at give sig i kast med. Men ikke alle har det på den måde. Nogle synes faktisk, at de altid har kunnet få deres undervisning til at fungere og har svcert ved at se, hvad teknologi kan gøre, som de ikke selv har klaret mindst ligeså godt. De ved heller ikke helt, hvordan de nogensinde skal komme rigtigt igang med e-laring. I omtalte mail opfordres de til at henvende sig med spørgsmål til fakultetets e-lceringskoordinator. Tcenk, de vidste slet ikke, de havde en sådan! Men det har de, og hun bliver kontaktet. 
Her slutter første del af historien om underviserne, der mere eller mindre frivilligt skal igang med at anvende universitetets nyerhvervede e-læringsplatform.

\section{Om at forstå sin organisation}

Alle erfaringer fra implementering af e-læring viser, at både undervisningen, de studerendes læreproces, og de administrative arbejdsprocesser ændres. Med e-læring er det muligt at gennemføre undervisning på andre måder end tidligere, hvilket selvfølgelig får betydning for både undervisere og studerende. De studerende har fået nye muligheder for at få adgang til materiale og andre læringsressourcer, og med de værktøjer, der er til rådighed i systemet, kan de kommunikere og samarbejde på mange forskellige måder. Også medarbejdere i de studieadministrative funktioner bliver berørt, idet de studieadministrative systemer i fremtiden skal levere data til e-læringssystemet for at understøtte, at de virtuelle klasseværelser bliver oprettet, at de rigtige studerende har adgang til de rigtige klasseværelser o. lign. Dermed ændres relationer, opgaver og kommunikation mellem undervisere, studerende og administration sig også. Der er mange steder behov for på ny at drøfte og aftale, hvem der har ansvaret for hvad.

Med sådanne nødvendige ændringer af daglige arbejdsprocedurer som de nævnte i baghovedet, er det ikke så mærkeligt, at overgangen kan virke voldsom og skræmmende og føre til blandede følelser hos nogle af organisationens medarbejdere. Mange oplever i forvejen et stor arbejdspres med store forventninger til deres performance. Anvendelse af e-læring kan derfor give frustrationer og i nogle sammenhænge stille spørgsmålstegn ved, om man har de kompetencer, organisationen har en forventning om, at man besidder.

For at mindske barrierer, som kan opstå som resultat af sådanne reaktioner, er det af stor betydning, at den udformede strategi tager udgangspunkt i et indgåede kendskab til og dermed analyse af organisationens forudsætninger for at handle og forandre sig, for at kunne forstå, hvor man vil hen og i hvilket tempo, det kan lade sig gøre. En analyse af styrker og svagheder i organisationens måde at handle på kan være hensigtsmæssig at foretage, forud for udformningen af strategien. Den kan 'afsløre', f.eks. hvis der i organisationen findes områder, der er behov for at tillægge særlig opmærksomhed, eller hvis der findes områder, som rummer særlige ressourcer.

Strategien bør forholde sig til forandringsprocesser og udfordringer, som indførelsen af e-læring vil medføre i organisationen, og skal beskrive, hvordan man vil håndtere og supportere denne forandringsproces, således at den løber af stablen på den mest hensigtmæssige måde. Hvis ikke disse forberedelser og overvejelser ligger til grund for strategi-udformningen, risikerer man at sidde med et stykke papir, der kun anvendes til festlige lejligheder og ellers samler støv på hylden.

\section{Fælles e-læringsplatform - fælles løsninger}

Hvis e-læring skal være en interesse for andre end frontløberne, der bliver udfordret af de teknologiske og de pædagogiske potentialer, de får til rådighed, er der en række barrierer, som må fjernes eller i det mindst gøres mindre vanskelige at forcere. En forudsætning for et velfungerende elæringssystem er, at der kan skabes sammenhæng og homogenitet i de systemer, som spiller sammen med e-læringssystemet. For at undgå en række manuelle arbejdsgange må der arbejdes med at få data leveret automatisk fra studieadministrative systemer som f.eks. STADS. Dette har imidlertid vist sig at fremkalde både systemmæssige og organisatoriske udfordringer. 
Medarbejderne i studieadministrationen på studiet har også drøftet det nye Blackboard. De har nu aftalt et møde med e-lceringskoordinatoren for at få at vide, hvordan de kan risikere at blive involveret. Da de får prcesenteret Blackboard, synes de faktisk, det har mange muligheder, som ville kunne være interessante for dem at afprøve. De kunne vælge, at alle beskeder om aflysning af undervisning blev lagt på Blackboard, og at der blev sendt en mail fra Blackboard til de studerende herom. Men de er usikre på om underviserne kunne finde på at cendre i de informationer og materialer, som administrationen lagger til de studerende. De kunne derfor godt ønske sig, at underviserne ikke fik helt de samme rettigheder til at cendre og redigere, som de har. Hertil siger e-læeringskoordinatoren, at det ikke vil kunne lade sig gøre, men at de i stedet må finde frem til, hvordan de vil dele opgaverne imellem sig, og hvordan de løbende kommunikerer om hvem der skal gøre hvad. Det er de godt klar over, men de tror ikke helt på, at det er tilstrcekkeligt!

SDU har for år tilbage valgt Blackboard, som et fælles system for alle medarbejdere og studerende på SDU, men en fælles e-læringsplatform er ikke nok til at samspillet fungerer. Den problemstilling forholder e-læringsstrategien sig til, og bl.a. derfor blev der vinter 2004 iværksat en ekstern undersøgelse af it-anvendelsen på SDU. Undersøgelsen, der gennemføres af PLS Rambøll Management, bliver afsluttet i efteråret 2004. I midtvejsrapporten, som gav det første statusbillede af it-situationen, kunne man for e-læringsområdet bl.a. læse:

- At det ser ud som om, at de it-mæssige problemstillinger ved en fælles e-læringsplatform optager mere i diskussionen end måske nødvendigt, fordi de strukturelle og organisatoriske barrierer er langt større og vanskeligere at håndtere;

- At det er påfaldende, hvor lidt de studerendes behov og interesser fylder i elæringsdiskussionen. Det er denne gruppe, som har den helt store interesse i, at SDU fremmer hele e-læringsområdet, og at dette sker med fælles initiativer og ensartede brugergrænseflader.

Kilde: http://intern.sdu.dk/it-service/Nyheder/IT-undersoegelsen/

Ovenstående udsagn er meget typiske for organisationer i forandringsprocesser - fokus flyttes fra mennesker til teknologi. Men det er vigtigt at fastholde, at de væsentligste forandringer ikke er på it-siden. Som omtalt tidligere er det vigtig at identificere "the culture change mountain", organisationen skal bestige, og som omfatter alle dele af organisationen. Det betyder, at alle medarbejdere skal have en forståelse for, at e-læring bliver en del af den normale praksis. E-læring skal derfor også indgå i de politikker og procedurer, som decentrale enheder udformer og arbejder efter. Dette fordrer, at også ledelserne føler sig forpligtede til at tage et medansvar og indgå aktivt i forandringsprocesserne. Derfor er beslutningen om, hvornår minimumskravene til anvendelsen af Blackboard i al undervisning på SDU også lagt ud på de enkelte fakulteter, således at de kan tage diskussionen og beslutte, hvornår de forventer at være klar - dog med seneste tidspunkt den 1 . september 2005.

Tilbage til vores case:

Underviserne har nu fået besked fra deres studiesekretcer om, at deres kurser er klar i Blackboard, og at deres studerende er tilmeldt. På fakultetet har man valgt at anvende holdoprettelsesmodulet i STADS, hvorved kurser automatisk oprettes med studerende. Andringer på holdene bliver justeret én gang i døgnet. Ikke alle fakulteter gør det på den måde. På et andet fakultet bliver kurserne oprettet af e-lceringskoordinatoren, og underviserne skal sørge for at informere 
de studerede om, at de selv skal tilmelde sig kurserne. Studiesekretceren fortceller desuden, at der på alle kurser er link til relevante studieordninger, de studerende kan finde en kursusbeskrivelse, og der er informationer om, hvor de kan komme i kontakt med undervisere og sekretcrer. Nu kan underviserne gå i gang med at lagge undervisningsmaterialer til de studerende ind på kurset. De kontakter deres e-læringskoordinator og aftaler et kursus, således at de kan få lcert systemet at kende samt finde frem til, hvordan de anvender e-lcering bedst muligt på deres hold. I første omgang er de mest interesserede i at få afprøvet systemet og anvende de mest almindelige funktioner. Så må de se, om de senere kan blive mere avancerede.

\section{Support}

Som det fremgår af den beskrevne case, er underviserne ikke helt sikre på, hvordan de kommer i gang. Overgangen til e-læring er en forandringsproces, som man skal være bevidst om og medtænke i strategien. På SDU gjorde vi os det klart, at: ”Der skal [...] udvikles nye kompetencer og læringsformer hos studerende og undervisere” (Syddansk Universitets E-læringsstrategi, p. 1). Support forbindes ofte med det at løse et teknisk problem, men vi var opmærksomme på, at support forbundet med indførelse af e-læring er flere ting: Brugere skal ikke bare have support til teknikken, men også til f.eks. organisering af det virtuelle klasseværelse og til pædagogiske potentialer på e-læringsplatformen. Vi har været fokuseret på at tilbyde alle typer af support.

Da vi (jf. undersøgelsen af IT-anvendelsen på SDU, se ovenfor) var blevet bekendt med, at de organisatoriske barrierer udgjorde større problemer end de tekniske, var vi meget fokuseret på at yde en support, der kan eliminere disse eller i hvert fald mindske dem væsentligt.

I en organisation som Syddansk Universitet, der i høj grad er decentralt organiseret og favner fire forskellige fakulteter med vidt forskellige traditioner, behov og krav, er det ikke muligt umiddelbart at definere den mest hensigtsmæssige organisering af support - og e-læring generelt. Således valgte vi på SDU en decentral organisering af e-læring. Vi var yderst bevidste om, at det var nødvendigt at skabe en struktur, der på den ene side har en central fælles enhed til at understøtte f.eks. den fælles e-læringsplatform, men på den anden side giver plads til decentrale behov. For at skabe og hele tiden fokusere på denne struktur, har vi nedsat en e-læringsorganisation, der spejler denne struktur: Det enkelte fakultet er repræsenteret i form af en e-læringskoordinator, der sammen med repræsentanterne fra de øvrige fakulteter, repræsentant(er) fra IT-service og Syddansk Universitetsbibliotek samt medarbejdere fra en central enhed kan stå til rådighed med hjælp og vejledning, når de retningslinier for brugen af Blackboard, der er udformet i forlængelse af SDUs e-læringsstrategi, skal udfoldes i praksis. Den valgte struktur kan siges at komplicere beslutningsprocesser i alle aspekter af implementeringen af en e-læringsstrategi og et e-læringssystem, men det er uden tvivl en nødvendig struktur i en organisation som SDU for at tilgodese både centrale og decentrale behov og krav. Et væsentligt kriterium for, at supporten fungerer, er, at de, der efterspørger den, ikke blot får svar i det øjeblik de savner det, men også selv har mulighed for at definere deres behov og den form for support, de søger.

Alle undervisere og administrativt ansatte inviteres til at deltage i korte arrangementer, hvor systemet præsenteres, og hvor der er mulighed for at diskutere og udveksle ideer til brug af systemet. Yderligere har vi åbnet mulighed for at afholde arrangementer i form af informationsmøder, hands on-kurser og lign, så disse kan tilpasses specifikke behov.

En væsentlig forskel mellem de ovenfor nævnte typer af support kan ligge i, i hvor høj grad de kan karakteriseres som værende problemløsende, brugsunderstøttende eller udviklingsfremmen- 
de. En problemløsende support (f.eks. ”...hvordan skal jeg rent teknisk løse en opgave i Blackboard for at følge de beskrevne minimumskrav?”) bliver nødvendigvis opsøgt, mens den mere brugsunderstøttende og udviklingsfremmende (gode muligheder, f.eks. pædagogiske fordele ved brug af systemet), som kan være med til at eliminere de organisatoriske barrierer, ikke altid gør det. Derfor valgte vi at udforme et supportsite i Blackboard:

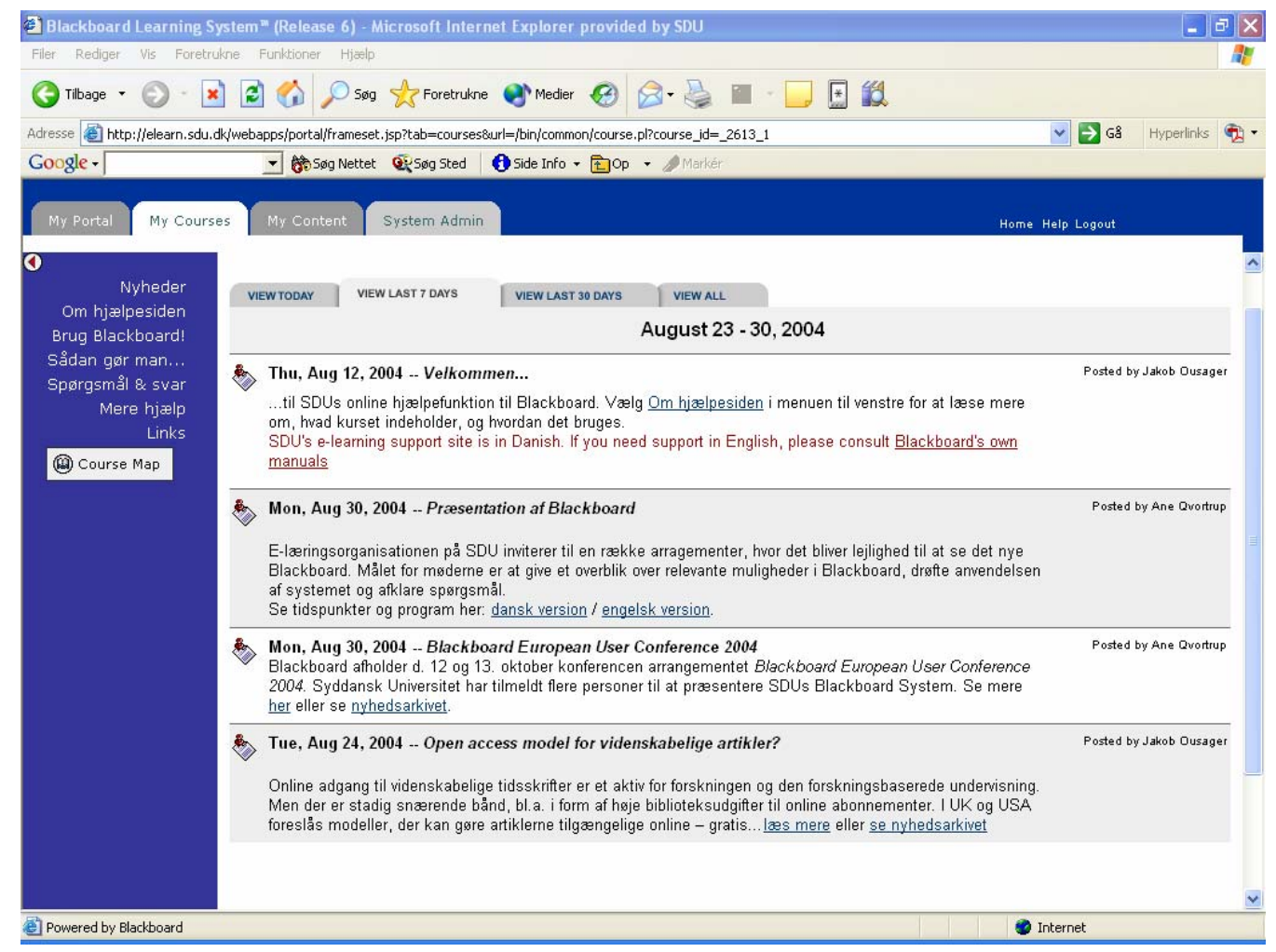

Dette site integrerer problemløsende, brugsunderstøttende og udviklingsfremmende support. Brugerne får i supportsitet ikke kun svar på tekniske spørgsmål og løsning på almindelige tekniske problemer, men kan også hente inspiration til, hvordan de mange forskellige funktioner, Blackboard-systemet stiller til rådighed, kan anvendes og udnyttes. Dette kan gøres via gode eksempler, hvilket netop er et væsentligt punkt i strategien: Viden om og erfaring med e-læring på SDU skal deles i det omfang, det er muligt. Desuden indeholder sitet et forum for erfaringsudveksling, hvor den enkelte bruger kan stille spørgsmål til og udveksle gode ideer med elæringsorganisationen og ikke mindst med Blackboards andre brugere.

\section{Midler til e-læringsprojekter}

En vigtig målsætning i e-læringsstrategien er udvikling af medarbejderkompetencer, således at elæring finder nye former og udtryk og dermed udvikles kontinuerligt. For at understøtte denne kompetenceudvikling og udvikling af e-læring, afsatte SDU $500.000 \mathrm{kr}$. til e-læringsprojekter i perioden 1.9.2004 til 1.9.2005. Projekter, der fik støtte skulle kunne demonstrere anvendelsen af og potentialer i Blackboard. En af barriererne for at komme i gang kan være manglende viden om de mange muligheder, der findes. Målet er, at de valgte projekter skal mindske barriererne ved at forbedre indsigten i rækken af muligheder og dermed stimulere interessen for anvendelsen af elæring i forskellige sammenhænge. I e-læringsstrategien lægges der vægt på, at anvendelsen af elæring på SDU skal bidrage til en kvalitetsudvikling af eksisterende og fremtidige undervisningsog forskningsaktiviteter. E-læringsstrategiens målsætninger er her blevet omsat til konkrete krav 
til ansøgningerne og projekterne. Når projekterne bliver sat i værk, vil det desuden betyde, at målene omsættes til aktiviteter, hvor medarbejdere får erfaringer med og viden om anvendelse af e-læring på deres eget område. E-læringsorganisationen har forpligtet sig til at sørge for koordinering og spredning af resultaterne fra projekterne. Der kom 20 forslag til projekter, og 12 blev godkendt til at kunne gå i gang. Her præsenteres et par af projekterne.

\section{Opslagstavle i Blackboard}

Biologisk institut ønsker at oprette en opslagstavle i Blackboard, hvor alle sekretærer og undervisere har adgang til at postere meddelelser samt sende e-mails. Der kan via opslagstavlen sendes besked til de studerende om f.eks. mødereferater, information om nye kurser, aktuelle gæsteforelæsere, reminders om ansøgningsfrister, informationer om fester og andre sociale aktiviteter. Opslagstavlen skal udformes med de funktioner, som brugerne efterlyser. Dernæst skal projektet være med til at etablere arbejdsprocedurer på sekretariatet som har den daglige drift af opslagstavlen. Endvidere skal de studerende instrueres i, hvordan de anvender opslagstavlen. Projektet gennemføres i løbet af efteråret 2004.

\section{Blackboard som virtuelt undervisningssystem}

Institut for organisation og ledelse er i gang med at udvikle og implementere nye undervisningsformer på Cand.merc. linien i International Management og vil udvikle minimum tre virtuelle kurser inden for fagområdet erhvervsøkonomi. Kurserne skal følges i Blackboard, og såvel danske som udenlandske studerende kan afprøve og blive testet for deres kvalifikationer før en eventuel optagelse på kandidatlinien. Kurserne skal fungere som støtte for erhvervsøkonomistuderende på bachelorniveau og som kvalitetssikring på optagelsessiden af studerende med anden baggrund (fagligt, kulturelt). Målet er, at undervisningssystemet skal kunne fungere globalt og geografisk uafhængigt, og dels højne kvaliteten af kandidatuddannelsen, dels give de studerende mulighed for at erhverve sig og/eller genopfriske basale erhvervsøkonomiske teorier og teknikker. Evaluering af de virtuelle fag skal ligeledes finde sted i Blackboard.

Læs om de øvrige projekter på SDUs e-læringshjemmeside: http://intern.sdu.dk/elearn/

\section{Fremtiden - udfordringer}

Der har i forbindelse med valg, indkøb og implementering af det nye Blackboard været en del fokus på teknikken og mulighederne i systemet, og det vil der fortsat skulle være. Ressourcerne skal dog koncentreres mere om de pædagogiske udfordringer og support, således at systemet anvendes til mere og andet end som materialedistribution. En af opgaverne i den forbindelse er at udvikle læringsressourcer i Blackboard om e-læringspædagogik og -didaktik.

Vi skal lige høre hvordan det går med lærerne inden vi slutter artiklen:

Lcererne er kommet godt i gang. Kurserne er oprettet, de studerende er tilmeldt, og der er lavet aftaler med studieadministrationen om, hvem der gør hvad og hvornår. Lærerne er nu i gang med at finde ud af, hvordan Blackboard kan bruges og selv de, der tidligere var tilbageholdne, synes det er spcendende. Det vcerste er nok at det tager tid, men det har de talt om, at de må finde gode løsninger på. De kunne jo overveje om e-læring kunne skrives ind i studieordningen, således at det også blev synliggjort, at der også fandt undervisning sted, når de studerende sad ved deres pc-ere derhjemme eller på campus. De er også noget overraskede over, at deres studerende forholder sig til kvaliteten af det, der sker i Blackboard. Nogle gange er de endda en smule krce- 
Tidsskrift for universiteternes efter- og videreuddannelse (ISSN 1603-5518). 1 årgang, nr. 4, 2004

vende, men på den anden side er det jo et udtryk for, at de er studieaktive. Så alt i alt er der store forventninger blandt leererne til, hvad de kan komme i gang med.

\footnotetext{
${ }^{i}$ SDUs e-læringsstrategi findes på flg. side: http://intern.sdu.dk/elearn/organisationen/strategi/

${ }^{\text {ii }}$ Udtrykket er hentet fra artiklen af Stiles, Mark, Staffordshire University: "Is an eLearning Strategy Enough? Educational Developements 5.1. Marts 2004. SEDA.
} 